\title{
Stand Characteristics and Leaf Litter Composition of a Dry Forest Hectare in Santa Rosa National Park, Costa Rica ${ }^{1}$
}

\author{
Robyn J. Burnham \\ Museum of Paleontology, University of Michigan, Ann Arbor, Michigan 48109-1079, U.S.A.
}

\begin{abstract}
One hectare of tropical dry forest in Guanacaste Conservation Area, Costa Rica was mapped and all trees larger than $10 \mathrm{~cm}$ diameter at breast height (DBH) identified. The same hectare was sampled for leaf litter and the two data sets, forest and litter, were compared. Dominant and subdominant species of the forest are represented in the leaf litter, whereas rare tree species arc highly variable in their representation in the leaf litter. Relative abundance of dominant and subdominant tree species is represented well by the litter although absolute rank-order is not identical between source forest basal area and leaf litter mass. The litter adds a significant component to the source forest data owing to the presence of vines and lianas, and more rarely small trees or shrubs. This indicates that litter studies may be able to add depth to forest diversity surveys. The source forest also was used to test foliar physiognomic reconstructions of climate that have been proposed recently by paleobotanists as an alternative to taxonomic affinities methods. The observed climate of the area does not conform to the climatic values that were predicted by application of these new methods.
\end{abstract}

\section{RESUMEN}

Una hectárea de bosque seco tropical en el Area de Conservación de Guanacaste, Costa Rica fue mapeada, y todos los árboles mayores de $10 \mathrm{~cm}$ de dap fueron identificados. En la misma hectárea, se tomaron muestras de hojarasca y los dos colecciones de datos, bosque y hojarasca, fueron comparadas. Se encontró que las especies dominantes y subdominantes del bosque estaban representadas en las muestras de hojarasca, mientras que la presencia de especias arbóreas raras en las muestras de mojarasca fue muy variable. La abundancia relativa de especies arbóreas dominantes está bien representada en la hojarasca aunque el área basal del bosque de origen y la masa de hojarasca no fueron idénticos en rangos absolutos. La hojarasca añade un componente significativo a los datos del bosque de origen debido a la presencia de bejucos y lianas en la hojarasca, y más raramente árboles pequeños y arbustos. Estos datos indican que los estudios de hojarasca pueden incrementar la precisión de las estimaciones de la diversidad de los bosques. El bosque de origen fue usado tambien para examinar reconstrucciones del clima basados en la fisiognomia foliar recientemente propuestas por paleobotánicas como una alternativa a métodos de afinidad taxonómicas. El clima observado en el área no corresponde con los valores climáticos que fueron predecidos por la aplicación de estos nuevos métodos.

\section{Keywords: biodiversity; conservation; fossil plants; Guanacaste; leaf litter; lianas; paleobotany; tropical dry forest.}

Tropical DRY FOREST HAS BEEN CITED as one of the most threatened forest ecosystems on earth today (Janzen 1988a, b) yet only recently has the phenology of dry forest been addressed by studies carried out in a variety of seasonally dry forests (Koelmeyer 1960, Janzen 1967, Daubenmire 1972, Frankie et al. 1974, Lieberman 1982, Reich \& Borchert 1984, Murphy \& Lugo 1986, Lott et al. 1987, Bullock et al. 1995, Martínez-Yrízar 1995, Murphy \& Lugo 1995). Tropical dry forest has been estimated to have covered as much as 500,000 $\mathrm{km}^{2}$ on the Pacific Coast of Central America as recently as 400 years ago (Janzen $1988 \mathrm{c}$ ). The relative ease of clearing dry tropical forest and its

${ }^{1}$ Received 23 October 1995; revision accepted 16 May 1996. adaptability to many forms of land use has resulted in its accelerated loss in the past two centuries (Maas 1995).

The forest and leaf litter characteristics of one hectare of forest in Santa Rosa National Park (SRNP), Costa Rica which represents a remnant of semi-deciduous dry tropical forest are described here. The objectives were to compare the composition and distribution of trees on the hectare to the identifiable leaf litter accumulating in the central part of the hectare, to determine whether a reasonable reconstruction of the forest could be made using leaf litter alone, and to use the forest as a test of regression analyses that are currently used to reconstruct paleoclimate.

The leaf litter collections and their comparison to the source forest can be used in two very differ- 
ent applications, one in conservation biology and extant forest assessment, and the other in paleobotanical reconstructions of fossil forests of Cenozoic age.

The questions asked by conservation biologists are:

1. Do leaf litter collections from a forest give a more accurate or more rapid assessment of the forest than a standard census of all trees larger than $10 \mathrm{~cm}$ diameter at breast height $(\mathrm{DBH})$ ?

2. Are elements of the forest found in leaf litter that otherwise would not be detected using commonly employed field censuses?

3. Is a combination of the two methodologies an improvement over the use of one or the other alone?

The questions asked by paleobotanists of the data presented here are:

1. Does the leaf litter represent the source forest in terms of species richness, diversity, composition, heterogeneity, and structure?

2. Are different life forms recognizable in the litter signature of a dry tropical forest?

3. What is the foliar physiognomy of this dry forest hectare and does it closely reflect the climate of the area, as suggested by currently used regression analyses?

Many fossil floras from the Western Interior of the United States ranging in age from Paleocene to Miocene could be interpreted as seasonally dry tropical to subtropical forests. The study of these fossil floras, although they do not share great floristic similarity to the forest at Santa Rosa National Park, would be aided by detailed physiognomic studies of similar modern floras from generally similar climatic settings. Data available from most fossil floras are not adequate to reconstruct the distribution of rainfall, however suggestions have been made that the Eocene floras from the Green River Formation (MacGinitie 1969), the Wilwood Formation and the Yellowstone Park floras (Wing 1987) and the Claiborne floras of the Atlantic Coastal Plain (Wolfe 1978) were representative of dry tropical or subtropical forests. Taxonomic, foliar physiognomic, and taphonomic studies on modern dry tropical forests are needed to determine the validity of paleoclimatic reconstructions of these types of fossil assemblages.

Previous work on leafing phenology in the dry lowland forests of Costa Rica, include Frankie et al. (1974) who focused on patterns of leafing in 113 species. These patterns were assessed in the canopy rather than by the resulting litter accumulation. Species whose phenology included periods of leaflessness comprised 75 percent of their species list. Timing of litterfall was demonstrated to be highly variable among individuals of three species from Costa Rica by Borchert (1983). Daubenmire (1972) followed phenologies of trees at nearby Cañas, Guanacaste Province, concluding that seasonal dryness was the major control on leaf senescence, rather than photoperiod.

\section{STUDY SITE}

The hectare of dry tropical forest studied is located in Santa Rosa National Park (SRNP), Guanacaste Conservation Area of northwest Costa Rica. The hectare was chosen for study because of the semideciduous nature of its canopy trees, which is a relatively rare condition for present forests of the area. This forest has experienced relatively less human disturbance than other forests of the region, with only Sweitenia macrophylla (mahogany) being removed by logging over the last 40 years, but little use is documented prior to that time (Janzen 1983). The forest may represent the condition of forests that are not influenced heavily by human activity, and may be a better model for ancient dry tropical forests than the more common, almost completely deciduous, forests that are at least in part a product of long-term disturbance by humans. In any case, the mix of deciduous and evergreen taxa gives the forest a phenological complexity that is not found in most wet tropical forests nor in dry or temperate deciduous forests.

Rainfall is markedly seasonal and variable from year to year. Janzen (1993) reports a range of 915 to $2558 \mathrm{~mm}$ per year with an average of $1614 \mathrm{~mm}$. Rain falls primarily between early April and early November, when average maximum temperatures are relatively low $\left(30-32^{\circ} \mathrm{C}\right)$, and the rest of the year is virtually without rain, with average maximum temperatures between 32 and $36^{\circ} \mathrm{C}$ (Daubenmire 1972, Janzen 1993). The study discussed here was carried out in late January and early February, 1994, at which time the forest had a continuous cover of foliage in the canopy, although many individual species were deciduous. The forest canopy was composed primarily of individuals of $H y$ menaea courbaril, Manilkara zapota, and Quercus oleoides, none of which bear synchronously deciduous leaves. 


\section{MAPPING AND COLLECTION METHODS}

FOREST MAPPING.-One hectare was mapped in the central portion of Bosque Humedo, about one $\mathrm{km}$ from the SRNP Administration Area. The forest has been used by Daniel $\mathrm{H}$. Janzen as a study site for mammal trapping and as a tree-fall study area (Janzen 1983). For reference with the grid system established by Janzen, this study was carried out in the hectare bounded by corners G8, Q8, G18, and Q18. The grid system used was divided into 25$20 \times 20 \mathrm{~m}$ quadrats in which each tree larger than $10 \mathrm{~cm} \mathrm{DBH}$ was measured, identified, and $\mathrm{X}$ and $\mathrm{Y}$ coordinates in the hectare recorded. All $10 \mathrm{~cm}$ DBH mapping, measurements and identification of the forest trees were made over a five day period in late January, 1994. Additional mapping of trees with diameters $5-10 \mathrm{~cm}$ was carried out in the central $60 \times 60 \mathrm{~m}$ area over a subsequent two day period in February 1994. These $5-10 \mathrm{~cm}$ data are excluded from all forest descriptions here unless expressly stated. The forest hectare included ridges on the east and west sides that appeared to influence species distributions, most notably of Quercus oleoides. All species identifications follow the taxonomic placement of Liesner and Janzen (1980).

LitTER COlLections. - Litter was collected from 0.5 $\times 0.5 \mathrm{~m}$ quadrats at 13 locations within the central $40 \times 40 \mathrm{~m}$ of the hectare, in the pattern shown in Figure 1. All litter was collected on 22 January 1994 with all identifiable leaf, fruit, and seed litter collected down to the level of the soil surface. Litter was separated to species, counted, dried to a constant weight, and weighed to the closest one-hundreth of a gram. Fruit and seed litter of all species was weighted separately and not included in mass reported here. Sterile reference specimens of the source trees were collected to aid in identification of dispersed leaf litter. Similar mapping and litter collection procedures have been followed by the author in forest hectares in Maryland, Virginia, Belize, and Manu National Park in Perú (Burnham et al. 1992, Burnham 1993, 1994). Leaf litter that was not assignable to any of the known species on the mapped hectare was given a morphotype name, cataloged, weighed, and for the purposes of the litter-source forest comparisons was counted only in the comparisons of total species richness per litter sample.

FOLIAR PHYSIOGNOMY.-The characteristics of angiosperm foliage, independent of taxonomic affin-

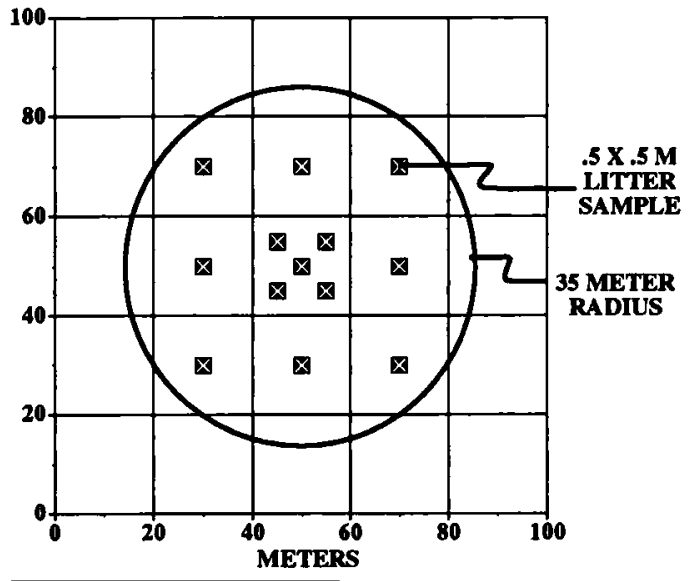

FIGURE 1. Location of litter samples on central $40 \times$ $40 \mathrm{~m}$ of Bosque Humedo, SRNP, Guanacaste Province, Costa Rica. Circle shows area of greatest quantitative similarily found between forest basal area and all combined litter samples using leaf litter mass as the descriptor for each litter species.

ities, have been used by paleobotanists in determining paleoclimate. A review of the range of methodologies now employed can be found in articles by Wolfe (1993) and Wing and Greenwood (1993). A data set of modern forest physiognomy and climate compiled by Wolfe (1993) and subjected to multivariate correspondence analysis (CLAMP) is particularly strong in sites from eastern and western United States, but has few data points in tropical wet and tropical dry climates. Wing and Greenwood (1993) recently devised a simple method to predict climate using multiple foliage characteristics using the same data set. This method may encourage re-evaluation of earlier estimates of paleoclimate where paleoaltitude estimates based on plants are difficult to reconcile with non-paleobotanical data (Gregory \& Chase 1992). The seasonally dry forest at Bosque Humedo is proposed as a test of the regression coefficients proposed by the new analysis of Wing and Greenwood (1993). The 56 tree species plus seven species of shrubs and vines on the Bosque Humedo hectare were scored for the seven foliage characters used by Wing and Greenwood (1993) to calculate seven climate parameters (Appendix 1). Their regression coefficients were applied to these foliage characters and the resulting estimates of climate compared with observed climate values taken from the literature (Daubenmire 1972, Coen 1983, Janzen 1993). 
TABLE 1. Species list of forest trees and leaf litter, showing percent basal area, percent number individuals; percent leaf mass, percent leaf number and coefficient of variation of littermass across 13 litter samples.

\begin{tabular}{|c|c|c|c|c|c|}
\hline Species & $\begin{array}{c}\text { Relative } \\
\text { basal } \\
\text { area }\end{array}$ & $\begin{array}{c}\text { Relative } \\
\text { stem } \\
\text { number }\end{array}$ & $\begin{array}{c}\text { Relative } \\
\text { leaf } \\
\text { litter } \\
\text { mass } \\
\end{array}$ & $\begin{array}{c}\text { Relative } \\
\text { leaf } \\
\text { litter } \\
\text { number }\end{array}$ & $\begin{array}{c}\text { Litter } \\
\text { coef- } \\
\text { ficient of } \\
\text { variation }\end{array}$ \\
\hline Quercus oleoides Cham. \& Schlecht. & 25.9 & 6.21 & 5.79 & 3.81 & 312.72 \\
\hline Hymneaea courbaril $\mathrm{L}$. & 18.49 & 7.63 & 38.57 & 48.95 & 83.04 \\
\hline Manilkara zapota (L.) V. Royen & 12.16 & 10.45 & 9.47 & 4.32 & 115.11 \\
\hline Sloanea terniflora (Moc. and Sesse) Standl. & 5.87 & 5.37 & 5.28 & 5.61 & 95.21 \\
\hline Luehea spp. & 5.2 & 8.47 & 3.68 & 1.05 & 246.81 \\
\hline Ficus sp. & 2.91 & 0.28 & 8.96 & 2.02 & 132.97 \\
\hline Dilodendron costaricense (Radlk.) Gentry \& Steyer. & 2.15 & 3.67 & 0.33 & 2.65 & 129.85 \\
\hline Calycophyllum candidissimum (Vahl) DC. & 2.12 & 2.82 & 2.76 & 2.06 & 137.92 \\
\hline Exostema mexicanum A. Gray & 1.9 & 4.8 & 0.55 & 0.18 & 210.23 \\
\hline Chrysophyllum cainito $\mathrm{L}$. & 1.65 & 1.98 & 0.32 & 0.35 & 270.28 \\
\hline Bombacopsis quinatum (Jacq.) Dugand & 1.63 & 0.56 & 0.97 & 0.75 & 315.37 \\
\hline Castilla elastica Cerv. & 1.55 & 2.26 & 1.73 & 0.24 & 301.44 \\
\hline Gliricidia sepium (Jacq.) Walp. & 1.55 & 0.56 & 0 & 0.00 & - \\
\hline Licania arborea Seem. & 1.41 & 0.56 & 0.03 & 0.03 & 236.23 \\
\hline Cedrela odorata $\mathrm{L}$. & 1.1 & 1.41 & 0.08 & 0.09 & 218.79 \\
\hline Spondias mombin $\mathrm{L}$. & 0.99 & 1.13 & 0.38 & 0.32 & 135.59 \\
\hline Guettarda macrosperma D. Sm. & 0.97 & 2.54 & 0 & 0.00 & - \\
\hline Annona purpurea Moc. \& Sesse & 0.95 & 3.39 & 0.85 & 0.18 & 295.01 \\
\hline Lysiloma sp. & 0.9 & 1.41 & 0.06 & 4.33 & 224.94 \\
\hline Eugenia sp. & 0.85 & 5.08 & 1.05 & 1.35 & 94.47 \\
\hline Ocotea veraguensis (Meisn.) Mez & 0.83 & 3.67 & 1.82 & 1.67 & 116.15 \\
\hline Ateleia herbert-smithii Pittier & 0.83 & 0.85 & 0 & 0.00 & - \\
\hline Brosimum alicastrum Swartz. & 0.72 & 1.41 & 0.84 & 0.63 & 319.21 \\
\hline Zuelania guidonia (Sw.) Britton \& Millsp. & 0.61 & 1.69 & 0.67 & 0.28 & 198.16 \\
\hline Erblichia odorata Seem. & 0.5 & 0.56 & 0 & 0.00 & 346.41 \\
\hline Bursera simaruba (L.) Sarg. & 0.47 & 0.56 & 0 & 0.00 & - \\
\hline Mouriri myrtilloides (Sw.) Poir & 0.46 & 2.82 & 1.25 & 3.05 & 87.28 \\
\hline Casearia silvestris $\mathrm{Sw}$. & 0.43 & 2.54 & 0.09 & 0.09 & 346.41 \\
\hline Tabebuia ochracea (Cham.) Standl. & 0.42 & 0.56 & 0.41 & 0.30 & 126.53 \\
\hline Sciadodendron excelsum Griseb. & 0.4 & 0.56 & 0 & 0.00 & - \\
\hline Rheedia edulis Triana \& Planch. & 0.39 & 1.13 & 2.34 & 0.98 & 158.00 \\
\hline Guazuma ulmifolia Lam. & 0.37 & 0.85 & 0.01 & 0.01 & 346.41 \\
\hline Sapitum thelocarpum & 0.3 & 0.85 & 0.06 & 0.01 & 346.41 \\
\hline Trichilia sp. & 0.29 & 1.13 & 0.06 & 0.09 & 225.69 \\
\hline Ardisia revoluta $\mathrm{HBK}$. & 0.29 & 0.85 & 0 & 0.00 & - \\
\hline Inga vera Willd. & 0.29 & 0.85 & 0 & 0.00 & - \\
\hline Ixora florbunda (A. Rich.) Griseb. & 0.27 & 0.56 & 0.28 & 0.08 & 250.08 \\
\hline Sebastiana confusa Lundell & 0.26 & 1.41 & 0.3 & 0.03 & 346.41 \\
\hline Casearia arguta $\mathrm{HBK}$. & 0.2 & 0.56 & 0.27 & 0.16 & 171.78 \\
\hline Krugiodendron ferrumi (Vahl) Urban & 0.18 & 0.56 & 0.25 & 0.37 & 240.80 \\
\hline Cochlospermum vitifolium (Willd.) Spreng. & 0.17 & 0.28 & 0.07 & 0.01 & 346.41 \\
\hline Cordia panamensis Riley & 0.16 & 0.85 & 0.22 & 0.04 & 316.45 \\
\hline Simarouba glauca DC. & 0.11 & 0.28 & 0.06 & 0.08 & 157.89 \\
\hline Casearia praecox Griseb. & 0.1 & 0.28 & 0 & 0.00 & - \\
\hline Dalbergia retusa Hemsl. & 0.09 & 0.28 & 0.24 & 0.01 & 346.41 \\
\hline Coccoloba \#10915 & 0.09 & 0.28 & 0 & 0.00 & - \\
\hline Cupania guatemalensis (Turcz.) Radlk. & 0.08 & 0.56 & 0 & 0.00 & - \\
\hline Agonandra macrocarpa L. O. Wms. & 0.07 & 0.28 & 0 & 0.00 & - \\
\hline Thouinidium decandrum (Humb. \& Bonpl.) Radlk. & 0.06 & 0.28 & 0 & 0.00 & - \\
\hline Picramnia quaternaria Donn. Sm. & 0.05 & 0.28 & 1.48 & 5.46 & 119.53 \\
\hline Rehdera trinervis (Blake) Mold. & 0.05 & 0.28 & 0 & 0.00 & - \\
\hline Sterculia apetala (Jacq.) Karst. & 0.04 & 0.28 & 0.1 & 0.03 & 346.41 \\
\hline Astronium graveolens (Jacq.) & 0.04 & 0.28 & 0 & 0.00 & - \\
\hline Apeiba tibourbou Aubl. & 0.04 & 0.28 & 0 & 0.00 & - \\
\hline Annona reticulata $\mathrm{L}$. & 0.04 & 0.28 & 0 & 0.00 & - \\
\hline Alibertia edulis A. Rich. & 0.04 & 0.28 & 0 & 0.00 & - \\
\hline Hirtella racemosa Lam. & 0 & 0 & 1.67 & 2.71 & 88.59 \\
\hline
\end{tabular}


TABLE 1. Continued.

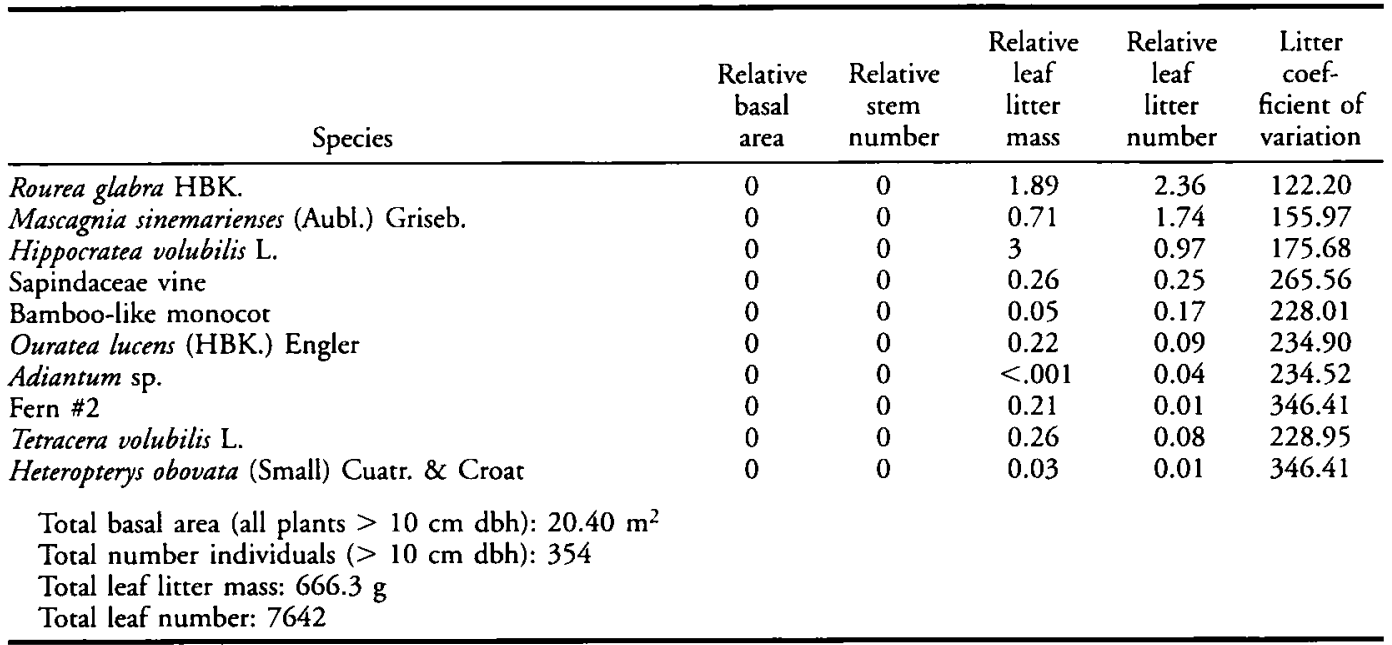

\section{RESULTS-FOREST CHARACTERISTICS}

SPECIES RICHNESS AND DOMINANTS.-The hectare of forest included 56 species with individuals larger than $10 \mathrm{~cm}$ diameter at breast height (DBH). A total of 354 individuals over $10 \mathrm{~cm} \mathrm{DBH}$ were mapped and identified (Table 1). The central 60 $\times 60 \mathrm{~m}$ area, which was also censused for trees between 5 and $10 \mathrm{~cm} \mathrm{DBH}$, add no additional species to the total species richness. The additional mapping substantially increased the number of individuals of four species, Eugenia myrtilloides, Ocotea veraguensis, Mouriri myrtilloides, and Picramnia quaternaria, which accounted for 72 percent of the individuals between 5 and $10 \mathrm{~cm} \mathrm{DBH}$ (and 71\% of the basal area of those individuals) in the central $60 \times 60 \mathrm{~m}$ area. Five species of vines or lianas and two shrubs, all with diameters less than $5 \mathrm{~cm}$ were noted in the hectare during mapping. These additional observations were casual however, and the total number of shrubs, herbs, and vine species was certainly larger.

Eight species comprised 74.8 percent of the total basal area of the trees over $10 \mathrm{~cm} \mathrm{DBH}$. All eight species contributed at least 2 percent to the total basal area (Table 1) and these were easily considered the dominants in the forest. An additional eight species collectively comprised an additional 11 percent of the total basal area. The remaining 40 species accounted for the remaining 15 percent of basal area, no species of which accounted for more then one percent of the total.
Fifteen species were represented by only one individual in the hectare, and 11 species were represented by only two individuals. Most species were represented by few individuals and only 12 species were represented by more than 10 individuals on the hectare.

DIVERSITY.-Species diversity calculated using the Shannon index $\left(\mathrm{H}^{\prime}\right)$ is 1.18 . This index normally ranges from 1 to 3.5 (Magurran 1988). Evenness in number of individuals of the tree species on the hectare was 0.68 , an index that varies between 0 and 1 , with 1 representing a community in which all species are equally abundant.

Heterogeneity and dispersion of trees.-Although the Shannon diversity index reflects the general distribution of individuals of all species, the distribution of individuals of the most important species gives a sense for the major differences from site to site within the hectare (Figs. 2 and 3). All individuals of Quercus oleoides were found on the easternmost $20 \times 100 \mathrm{~m}$ section of the hectare, while individuals of Hymenaea courbaril were distributed in a very broad diagonal running from the NE to SW corners. Manilkara zapota was distributed fairly evenly across the hectare with only 7 of the $2520 \times 20 \mathrm{~m}$ cells lacking at least one individual. Luehea, another dominant tree on the hectare was primarily distributed in the same $20 \times 100 \mathrm{~m}$ area occupied by Quercus oleoides. Scattered individuals of Luehea did occur elsewhere in the plot, although 

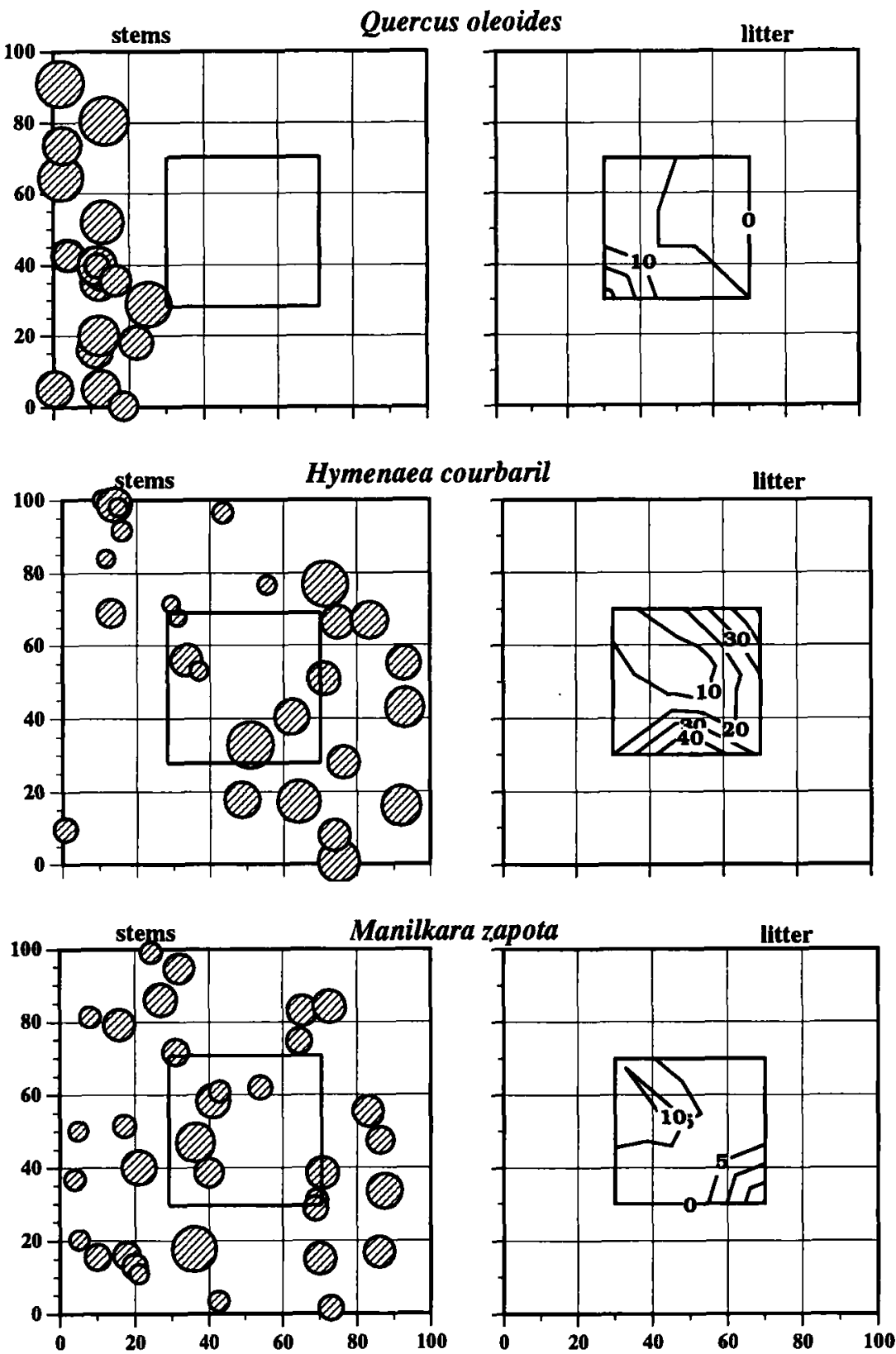

FIGURE 2. Tree and litter distribution of Quercus oleoides, Hymenaea courbaril, and Manilkara zapota a. Position and relative stem size of all individuals on the hectare. b. Mass of litter of same species collected in the center $40 \times$ $40 \mathrm{~m}$ area. Lines of equal value are interpolated.

they were considerably more rare than in the eastern $1 / 5$ of the hectare. One individual of Ficus sp. was present on the hectare where it was strangling a Gliricidia sepium. Its canopy was spread over a $45 \times 45 \mathrm{~m}$ area, certainly the largest canopy on the hectare.

\section{RESULTS-LEAF LITTER CHARACTERISTICS}

SPECIES RICHNESS AND DOMINANTS.-When pooled, all 13 litter samples contained a total of 49 species, 11 of which were not trees and therefore do not 

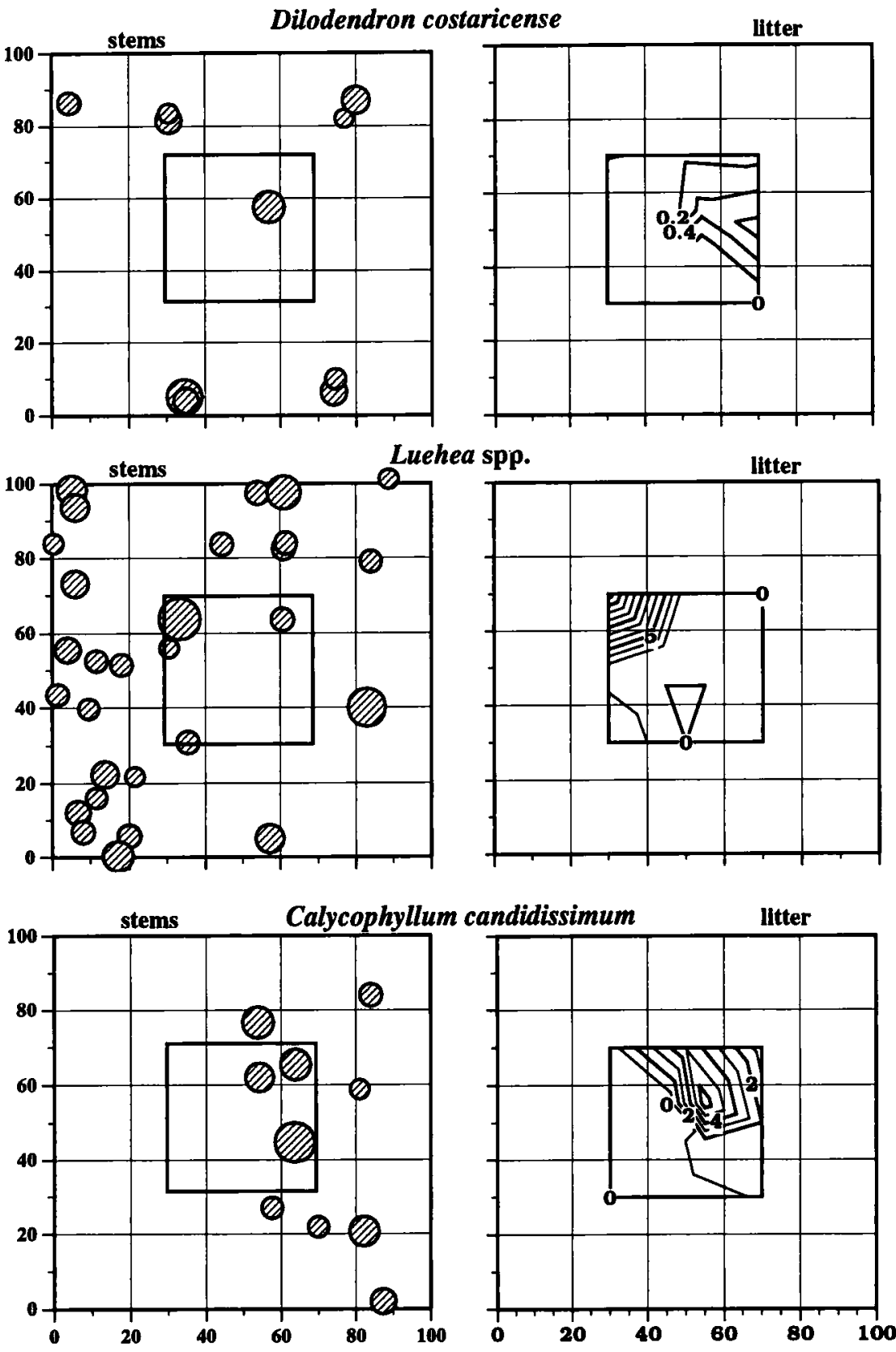

FIGURE 3. Tree and litter distribution of Dilodendron costarecense, Luehea sp., and Calycophyllum candidissimum a. Position and relative stem size of all individuals on the hectare. b. Mass of litter of same species collected in the center $40 \times 40 \mathrm{~m}$ area. Lines of equal value are interpolated.

overlap with the species composition from the source trees. Individual samples included from 17 to 33 species (mean $=23$ ), and individual samples included from 21 to 41 percent of all tree species found on the hectare. All combined samples included 70 percent ( 38 of 56 ) of the species list of trees over $10 \mathrm{~cm} \mathrm{DBH}$. All taxa found among the leaf litter samples are listed in Table 1. The six most important species in the litter mass were the same as the six most dominant forest trees, although the order is not the same between the two lists. Two species whose rank order numbers were seven and 
nine in the litter were lianas, Hippocratea volubilis and Rourea glabra, neither of which reached the 10 cm DBH limit used for mapping stems.

When evaluated individually, each litter sample included from 6 to 9 of the 15 dominant species in a source tree list derived from a circular area of $20 \mathrm{~m}$ diameter surrounding each sample site. Conversely, the source tree list from that $20 \mathrm{~m}$ diameter area included from 6-9 of the 15 dominant species from the corresponding litter sample. Each sample was thus a poor representation (often less than 50 percent of the source trees included) of even a small area of forest trees surrounding the sample. Significantly, included in the 15 dominant species in each litter samples were from $1-4$ species of climbing plants.

DiversitY.-Species diversity of the leaf litter, calculated using the Shannon index $\left(\mathrm{H}^{\prime}\right)$, was 0.97 for the combined samples with an evenness of 0.58 . Individual samples ranged from $\mathrm{H}^{\prime}=0.51$ to 1.11 and evenness $=0.42$ to 0.83 .

HeterogeneitY.-Site to site variation in litter was high in the hectare studied, similar to other tropical sites sampled (Burghouts et al. 1994, Burnham 1994). This variation reflects the distribution of the large source trees of the immediate area. Figures 2 and 3 show the distribution of trees $\geq 10 \mathrm{~cm} \mathrm{DBH}$ of individual species on the hectare and litter mass of that same species in the central portion of the hectare. It is significant that a tree $\geq 30 \mathrm{~cm} \mathrm{DBH}$ at a distance of $20 \mathrm{~m}$ from the litter collecting area has little or no influence on total mass or abundance (see especially Luehea, Quercus, Dilodendron). Quercus oleoides shows one of the most drammatically variable distributions among species in the litter. It was represented by 269 leaves (35.1 $\mathrm{g}$ ) in one sample, and by only 10 leaves in two additional samples $(1.26 \mathrm{~g}$ and $2.09 \mathrm{~g})$, one leaf in a fourth sample, and none in any other samples. This reflects well the non-uniform distribution of source trees of Quercus oleiodes.

Another measure of variability among samples for individual species can be assessed simply using the coefficient of variation (CV) of litter mass, calculated for each species across all samples. Because the coefficient of variation is scaled by species mean weight, it can be compared across species (Table 1). Trees that occurred in every $20 \times 20 \mathrm{~m}$ cell had low $C V(<150)$ in the litter, regardless of whether their total mass was high (Hymenaea courbaril, Sloanea terniflora) or low (Picramnia quaternaria). Trees that occurred in few or clumped 20

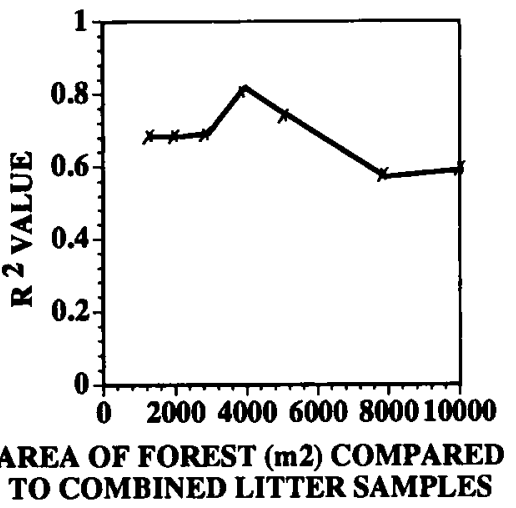

FIGURE 4. Comparison of $R^{2}$ values derived from regression of proportion of litter mass in all samples on proportion basal area of 25 most important species in forest areas of various sizes. All proportions for each species are arc-sin transformed prior to regression.

$\times 20$ cells had high CV $(>200)$ in the litter, regardless of whether their total mass was high (Quercus oleoides, Luehea spp.) or low (Brosimum alicastrum). Species represented by a few trees (1-3) on the hectare usually were represented by none or a few leaves with a clumped distribution that gave a high CV (e.g., Cochlospermum, Sapium, Krugiodendron). Shrubs and vines that are common and probably important photosynthetic contributors also showed a low coefficient of variation (Hirtella, Rourea, Hippocratea).

FOREST REPRESENTED BY LITTER SAMPLES, - Litter samples from the central $40 \times 40 \mathrm{~m}$ area do not incorporate litter from all trees on the hectare. The area of best representation of these litter samples is certainly smaller than the $100 \times 100 \mathrm{~m}$ area mapped. To determine the forest area best represented by the 13 litter samples, circles of forest 20 $\mathrm{m}$ to $60 \mathrm{~m}$ radius were compared to the litter, excluding all leaves of species of non-trees. Comparisons were made between species proportion of total litter mass for all collections to total proportion of basal area of the 25 most important species for that forest area. Regression results for each radius are reported in Figure 4. Best representation of the forest to the 13 litter samples is a circle with radius $35 \mathrm{~m}$, a forest area of $3848 \mathrm{~m}^{2}$. This area is shown in Figure 1 in relation to the litter samples.

FOREST PHYSIOGNOMY.-Comparison of climatic parameters calculated from foliage characters and actual values observed at SRNP by park rangers or from data at Cañas, Costa Rica are compared in 
TABLE 2. Comparison of climate based on calculations from regression analyses based on foliar physiognomy with actual values at SRNR, Guanacaste Province, Costa Rica.

\begin{tabular}{lll}
\hline \multicolumn{1}{c}{ Parameter } & Calculated & Actual \\
\hline Mean annual temperature & $19.9^{\circ} \mathrm{C}$ & $27^{\circ} \mathrm{C}$ \\
Mean annual range & $9.6^{\circ} \mathrm{C}$ & $\sim 10^{\circ} \mathrm{C}$ \\
Cold month mean & $13.2^{\circ} \mathrm{C}$ & $\sim 21^{\circ} \mathrm{C}$ \\
Warm month mean & $30.9^{\circ} \mathrm{C}$ & $32-34^{\circ} \mathrm{C}$ \\
Mean annual precipitation & $2117 \mathrm{~mm}$ & $1614 \mathrm{~mm}$ \\
Three dry month precipitation & $320 \mathrm{~mm}$ & $0 \mathrm{~mm}$ \\
Total growing season precipitation & $2067 \mathrm{~mm}$ & $1614 \mathrm{~mm}$ \\
\hline
\end{tabular}

Table 2. Of the climatic parameters estimated from foliage characteristics, only mean annual range of temperature was accurately estimated from the application of the published regression coefficients (Wing \& Greenwood 1993). In general the forest physiognomic estimate gives a picture of a cooler, less equable climate in which rainfall is seasonal but more abundant throughout the year.

\section{DISCUSSION}

In general it is clear that leaf litter accurately reflects the forest from which it is derived. Although total species richness is not available directly from litter assemblages, the relative richness of litter samples does reflect the relative richness of forests from which they are derived (Burnham 1993), and with some continued sampling of modern forests, it may be possible to construct conversion factors for estimates of total species richness. In complex, dry semi-deciduous forest, we are faced with the most difficult situation under which litter is compared to the source forest: not all species are synchronous in their leaf flushing and shedding. Even so, the litter of this forest gives clear signals on which species are dominant and subdominant on the hectare, and on the relative importance of the individual species. The specific uses to which these data might be applied are outlined below.

\section{Conservation biology.-}

1. Do leaf litter collections from a forest give a more accurate or more rapid assessment of the forest than a standard census of all trees larger than $10 \mathrm{~cm}$ diameter at breast height $(\mathrm{DBH})$ ?

Each part of this study (forest stem vs. litter) required about the same amount of time by the principal investigator ( $5 \mathrm{~d}$ ). All leaf litter samples were separated, counted, dried, and weighed by the author alone, so an advantage that might acrue to leaf litter sampling over forest stem mapping is that the task can be accomplished more easily by an isolated investigator. Leaf litter collections did not reconstruct the total species richness of the hectare of forest, in spite of intense sampling an area of 40 $\times 40 \mathrm{~m}$. The litter samples represent only 70 percent of the total tree species richness and 80 percent of the species in the most representative area $(3 / 8 \mathrm{ha})$. However the litter samples account for the species that make up 94.6 percent of the total basal area of the hectare. The forest litter species list thus represents well the dominant and subdominant tree species on the hectare. One-time litter censuses of fruits and seeds does not add substantially to the study, however it should be noted that at least one vine (Byttneria: Sterculiaceae) was found only as dispersed fruits in the litter samples, never as leaves and never counted among the stems.

Under some situations, leaf litter collection rather than forest stem mapping is recommended. When field time is limited and cannot be dedicated to mapping, leaf litter identification and counting can be carried out after returning from a remote field area.

2. Are elements of the forest found in leaf litter that otherwise would not be detected using standard $10 \mathrm{~cm} \mathrm{DBH}$ field assessment?

Many forests throughout the world have been mapped using a $10 \mathrm{~cm}$ DBH minimum limit. Although this level of mapping does not describe the community of smaller individuals of any species, the total diameters do correlate well with leaf mass studies from the same forests (Burnham et al. 1992, Burnham 1994). Smaller individuals, while important to community health and stability, are not reflected in litter because of their small biomass produced yearly. Two exceptions to this pattern noted here are Picramnia quaternaria and Mouriri myrtilloides, which are scarcely represented in the $10 \mathrm{~cm}$ diameter limit data $(.05$ and $.46 \%$ of total basal area), but are well represented in the $5-10 \mathrm{~cm}$ diameter data (16 and $23 \%$ of total basal area, re- 
spectively, of the 5-10 cm diameter trees). Their leaves are abundant in the litter, contributing up to 17 percent in some samples by number, but still relatively low in leaf mass $(0-6 \%$ of total leaf mass per sample). The litter samples indicate their importance on the hectare, and in the case of an understorey tree, this importance would not be noted in studies limited to $10 \mathrm{~cm}$ diameter and larger trees.

Similarly, vines and lianas rarely are noted in forest censuses, both because their diameters are small and because vines and lianas are relatively more difficult to collect and identify than forest trees (Gentry 1991). Five species of lianas were found in the leaf litter samples, two of which are consistently abundant in the litter samples, Hippocratea volubilis and Mascagnia sinemariensis (c.v. $=155$ and 175, respectively). Only through litter sampling or an intensive survey of vines and lianas would elements like these be included in a forest survey. Species richness is increased by 7 to 26 percent per sample in the hectare sample by vines and lianas alone. These data suggest that litter studies add two distinct dimensions to standard sampling techniques: information on small, abundant individuais and on non-trees that are important in the photosynthetic total for the forest.

3. Is a combination of the two methodologies an improvement over the use of one or the other alone?

The comparative value of the methodologies explored here should be assessed based on the questions posed by census and survey teams. It appears that when total species richness is the question, samples of leaf litter alone will add vine and liana taxa that would otherwise be omitted with stem surveys, yet they omit rare forest trees. Thus the combination of litter collections and stem maps clearly improves the description of a forest. A litter survey alone should be considered for forests in which tree species identities are known and for which current photosynthetic importance values (leaf litter) are preferred over those that reflect recent forest history (stem measurements) as suggested by Parker et al. (1989).

\section{Paleontology.-}

1. Does the leaf litter represent the source forest in terms of species richness, diversity, composition, heterogeneity, and structure?

Leaf litter reflects only 70 percent of the tree species on the hectare, but was very good at representing the dominant and subdominant species
(94.6\% of basal area). Location of trees in the forest was well reflected by the litrer, although because canopy shape is not perfectly symmetrical in most individuals, the litter did not always reflect a perfect circle around the bole of a tree. Heterogeneity of litter reflects heterogeneity in the forest.

The most interesting aspect of the comparison between forest and litter is the large number of species that are found in the litter that are not part of the tree species list. In this hectare, 11 species were found in litter that came from small trees (Hirtella racemosa), lianas (Rourea, Hippocratea, Mascagnia, Tetracera), and herbs, particularly ferns. This illustrates the importance of non-trees in potential fossil deposits. Most of these taxa are highly patchy in distribution, with coefficient of variation values that are high. However three vines and one shrub have low c.v. and might easily be mistaken in the fossil record for important, but relatively small trees, if alternative concepts of plant habit were not entertained.

The heterogeneity of the dry forest hectare is well reflected in the Shannon indices and in the distribution of litter in the central area of the hectare. If samples of this type can be made using remains from the fossil record, a very good description of ancient heterogeneity and structure appear to be possible.

2. Are different life forms recognizable in the litter signature of a dry tropical forest?

As discussed above, different life forms, particulary vines and shrubs, are potentially a problem in reading forest structure from the litter without knowing the plant habit represented. There is no indication from the leaf litter data derived from the SRNP dry forest that plant habit can be determined based on the distribution of litter alone. Dominant trees are the only plants that show low coefficient of variation among samples and contribute consistently large leaf numbers and mass to the litter.

3. What is the foliar physiognomy of this dry forest hectare and does it closely reflect climate, as suggested by currently used regression analyses?

The foliar physiognomic method, utilizing regression analyses based on a data set strong in temperate sites, but weaker in tropical wet and dry forest sites, does not appear to reconstruct climate correctly at Santa Rosa National Park. In particular, the mean annual temperature is incorrectly estimated as seven degrees cooler than the actual temperature at the site today. Total annual precipitation is over estimated by about 25 percent. The 
forest area studied is in a particularly well protected and moist part of Santa Rosa National Park, and it could be argued that the calculated precipitation values reflect the soil moisture characteristics of Bosque Humedo not total precipitation. A parallel study on a hectare of mature dry deciduous forest in SRNP could address this issue. Continued studies of modern climates for the purpose of devising means for predicting paleoclimates should certainly incorporate data on soil moisture characteristics.

An older, alternative method for estimating mean annual paleotemperature uses the positive correlation between proportion of entire margined species in a flora and paleotemperature (Bailey \& Sinnott 1916, Wolfe 1978). Using this correlation, a mean annual temperature of $20-22^{\circ} \mathrm{C}$ is obtained, which is closer to the actual value, but still five degrees or more cooler than the observed temperatures. It must be concluded that our knowledge of the relationship between foliar physiognomy and climate is far from complete.

Continued research on the relationship between modern leaf morphology and current climate regime are needed if paleobiologists are to refine methods for estimating paleotemperatures. An expanded network of tropical and subtropical areas in which the relationships between climatic parameters and leaf morphology can be evaluated is desperately needed. In addition, analysis of leaf morphology, with specific reference to rainfall distribution, soil type, and elevation may be important in reducing the uncertainty that now exists in assigning paleofloras to climatic regime.

\section{ACKNOWLEDGMENTS}

I appreciate field assistance and review of an earlier draft of this manuscript by E. S. Jules. Later drafts of the manuscript benefited substantially from comments by B. Haines, F.N. Scatena, and an anonymous reviewer. Enormous help in identifying plants in the field was provided by Roberto Espinosa. Robin B. Foster was encouraging and helpful in identifying fragments of plants brought back to the United States. William R. Anderson kindly identified specimens of Malpighiaceae. Martin Timana generously edited the Spanish abstract. Daniel $\mathrm{H}$. Janzen provided helpful comments about the forests at SRNP. The Guanacaste Conservation Area gave permission to work in the forest at Bosque Humedo. This research was supported by NSF Grant EAR-9316316 and the American Philosophical Society.

\section{LITERATURE CITED}

Balley, I. W., ANd E. W. SinnotT. 1916. The climatic distribution of certain types of angiosperm leaves. Am. J. Bot. 3: 24-39.

Borchert, R. 1983. Phenology and control of flowering in tropical trees. Biotropica 15(2): 81-89.

Bullock, S. H., H. A. Mooney, and E. Medina. 1995. Seasonally dry tropical forests. Cambridge University Press, Cambridge, England.

Burghouts, T. B. A., E. J. F. Campbell, and P. J. Kolderman. 1994. Effects of tree species heterogeneity on leaf fall in primary and logged dipterocarp forest in the Ulu Segama Forest Reserve, Sabah, Malaysia. J. Trop Ecol. 10: 1-26.

Burnham, R. J. 1993. Reconstructing richness in the plant fossil record. Palaios 8: 376-384.

. 1994. Patterns in tropical leaf litter and implications for angiosperm paleobotany. Rev. Palaeobot. Palynol. 81: 99-113.

- S. L. WING, AND G. G. PARKer. 1992. The reflection of deciduous forest communities in leaf litter: implications for autochthonous litter assemblages from the fossil record. Paleobiology 18(1): 34-53.

Coen, E. 1983. Climate. In D.H. Janzen (Ed.). Costa Rica Natural History, pp. 35-46. University of Chicago Press: Chicago, Illinois.

Daubenmire, R. 1972. Phenology and other characteristics of tropical semi-deciduous forest in northwestern Costa Rica. J. Ecol. 6: 147-170.

Frankie, G. W., H. G. Baker, and P. A. Opler. 1974. Comparative phenological studies of trees in tropical wet and dry forests of the lowlands of Costa Rica. J. Ecol. 62: 881-913.

Gentry, A. H. 1991. The distribution and evolution of climbing plants. In F. E. Putz and H. A. Mooney (Eds.). The biology of vines, pp. 3-52. Cambridge University Press, Cambridge, England.

Gregory, K. M., And C. M. Chase. 1992. Tectonic significance of paleobotanically estimated climate and altitude of the late Eocene erosion surface, Colorado. Geology 20: 581-585.

JANZEN, D. H. 1967. Synchronization of sexual reproduction of trees within the dry season in Central America. Evolution 21: 620-637.

1983. No park is an island: increase in interference from outside as park size decreases. Oikos 41: 402 410.

1988a. Tropical dry forest: the most endangered major tropical ecosystem. In E. O. Wilson (Ed.). Biodiversity, pp. 130-137. National Academy Press, Washington, D.C.

1988b. Management of habitat fragments in a tropical dry forest: Growth. Ann. Mo. Bot. Gard. 75: 105116. 
1988c. Guanacaste National Park: Tropical ecological and biocultural restoration. In J. Cairns, Jr. (Ed.). Rehabilitating damaged ecosystems Vol II, pp. 143-192. CRC Press: Boca Raton, Florida.

1993. Caterpillar seasonality in a Costa Rican dry forest. In N. E. Stamp and T. M. Casey (Eds.). Caterpillars: Ecological and evolutionary constraints on foraging, pp. 448-477. Chapman and Hall, New York.

KOELmeYer, K. 1960. The periodicity of leaf change and flowering in the principal forest communities of Ceylon. II. Phenology of the tropical dry mixed evergreen forest. Ceylon For. 4: 308-364.

Lieberman, D. 1982. Seasonality and phenology in a dry tropical forest in Ghana. J. Ecol. 70: 791-806.

Liesner, R., and D. H. Janzen. 1980. Annotated check-list of plants of lowland Guanacaste Province, Costa Rica, exclusive of grasses and non-vascular cryptogams. Brenesia 18: 15-90.

Lott, E. J., S. H. Bullock and J. A. Solis-Magallanes. 1987. Floristic diversity and structure of upland and arroyo forests of coastal Jalisco. Biotropica 19(3): 228-235.

MAAS, J. M. 1995. Conversion of tropical dry forest to pasture and agriculture. In S. H. Bullock, H. A. Mooney, and E. Medina, (Eds.). Seasonally dry tropical forests, pp. 399-422. Cambridge University Press, Cambridge, England.

MacGinitie, H. D. 1969. The Eocene Green River flora of northwestern Colorado and northeastern Utah. University of California Publications in Geological Sciences 83: Berkeley, California.

Magurran, A. E. 1988. Ecological diversity and its measurement. Croom Helm: London, England.

Martínez-Yrízar, A. 1995. Biomass distribution and primary productivity of tropical dry forests. In S. H. Bullock, H. A. Mooney, and E. Medina, (Eds.). Seasonally dry tropical forests, pp. 326-345. Cambridge University Press, Cambridge, England.

Murphy, P. G., AND A. E. Lugo. 1986. Ecology of tropical dry forest. Annu. Rev. Ecol. Syst. 17: 67-88. 1995. Dry forests of Central America and the Caribbean. In S. H. Bullock, H. A. Mooney, and E. Medina, (Eds.). Seasonally dry tropical forests, pp. 9-34. Cambridge University Press, Cambridge, England.

Parker, G. G., J. P. O'Neil.t, and D. Higman. 1989. Vertical profile and canopy organization in a mixed deciduous forest. Vegetatio 85: 1-11.

Reich, P. B., ANd R. Borchert. 1984. Water stress and tree phenology in a tropical dry forest in the lowlands of Costa Rica. J. Ecol. 72: 61-74.

WING, S. L. 1987. Eocene and Oligocene floras and vegetation of the Rocky Mountains. Ann. Mo. Bot. Gard. 74(4): 748-784.

- ANd D. R. Greenwood. 1993. Fossils and fossil climate: the case for equable continental interiors in the Eocene. Phil. Trans. R. Soc. Lond. B, 341: 243-252.

WOLfE, J. A. 1978. A paleobotanical interpretation of Teritary climates in the northern hemisphere. Am. Sci. 66(6): $694-703$.

1993. A method of obtaining climatic parameters from leaf assemblages. U. S. Geol. Survey Bull. 2040: 1-73. 